\title{
Identification of the Proteasome Inhibitor MG262 as a Potent ATP- Dependent Inhibitor of the Salmonella enterica serovar Typhimurium Lon Protease ${ }^{\dagger}$
}

\author{
Hilary Frase, Jason Hudak, and Irene Lee \\ Department of Chemistry Case Western Reserve University, Cleveland, Ohio 44106
}

\begin{abstract}
Lon is a homo-oligomeric ATP-dependent serine protease which functions in the degradation of damaged and certain regulatory proteins. The importance of Lon activity in bacterial pathogenicity has led to its emergence as a target in the development of novel antibiotics. As no potent inhibitors of Lon activity have been reported to date, we sought to identify an inhibitor which could serve as a lead compound in the development of a potent Lon-specific inhibitor. To determine whether a nucleotide- or peptide-based inhibitor would be more effective, we evaluated the steady-state kinetic parameters associated with both ATP and peptide hydrolysis by human and Salmonella enterica serovar Typhimurium Lon. Although the ATP hydrolysis activities of both homologs are kinetically indistinguishable, they display marked differences in peptide substrate specificity. This suggests that a peptide-based inhibitor could be developed which would target bacterial Lon, thereby decreasing side-effects due to cross-reactivity with human Lon. Using Salmonella enterica serovar Typhimurium Lon as a model, we evaluated the $I C_{50}$ values of a series of commercially available peptide-based inhibitors. Those inhibitors which behave as transition state analogs were the most useful in inhibiting Lon activity. The peptidyl boronate, MG262, was the most potent inhibitor tested $\left(I C_{50}=122 \pm 9 \mathrm{nM}\right)$ and required binding, but not hydrolysis of ATP to initiate inhibition. We hope to use MG262 as a lead compound in the development of future Lon specific inhibitors.
\end{abstract}

The number of pathogenic, antibiotic resistant bacteria increases each year, however the development of new antibiotics to treat them lags behind (1). Recent studies aimed at identifying proteins necessary for virulence have implicated the importance of Lon protease $(2,3)$. Pathogenic Salmonella enterica are responsible for causing a range of human diseases from mild gastroenteritis (serovar Typhimurium and serovar Enteritidis) to typhoid fever (serovar Typhi). It has been demonstrated that Salmonella enteria serovar Typhimurium ( $S$. Typhimurium) Lon protease activity is required for systemic infection in mice, a common study model for $S$. Typhi infection in humans (3). In fact, Lon-deficient $S$. Typhimurium, when administered as an oral vaccine to mice, conferred subsequent protection against infection by virulent $S$. Typhimurium (4). Taken together, these studies highlight Lon as an important target in the development of novel therapeutic agents.

Lon, also known as the protease La, is a homo-oligomeric ATP-dependent serine protease, which functions in the degradation of damaged and certain short-lived regulatory proteins (5-14). Homologs exist ubiquitously in nature, however they localize to the cytosol in prokaryotes and to the mitochondrial matrix in eukaryotes $(8,15,16)$. Sequence alignment of

\footnotetext{
${ }^{\dagger}$ This work was support by the NIH grant GM067172. J. H. is the recipient of the SPUR fellowship, a program sponsored by the Howard Hughes Medical Institute.

* corresponding author, phone: 216-368-6001, email: irene.lee@ case.edu, fax: 216-368-3006.
} 
the human, Escherichia coli (E. coli), and S. Typhimurium Lon proteases has revealed that the bacterial enzymes share greater than $99 \%$ sequence identity, but only $42 \%$ identity with their human homolog (17). In fact the $E$. coli and $S$. Typhimurium Lon proteases differ in only 3 amino acids, none of which occur within the functional domains of the enzyme, indicating the two may function comparably. This is supported by the fact that Lon-deficient $E$. coli and $S$. Typhimurium are indistinguishable in their increased sensitivity to UV light and other DNA damaging agents, as well as their decreased ability to degrade abnormal proteins $(11,18-23)$.

Lon protease is a member of the $\mathrm{AAA}^{+}$superfamily (ㅈPases $\underline{\mathbf{A}}$ ssociated with different

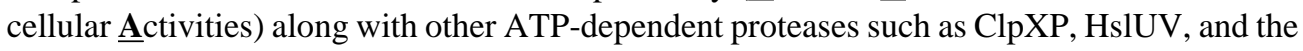
proteasome $(24,25)$. These proteins all share a common ATPase domain consisting of the Walker A and B motifs. Both Lon and HslUV, the bacterial homolog of the proteasome, undergo a conformational change upon ATP binding $(26,27)$. Crystallographic studies of a truncated Lon mutant have suggested that Lon utilizes a Ser-Lys dyad to catalyze proteolysis, similar to the Thr-N terminal amino group dyad used by the proteasome $(28,29)$. Furthermore, both Lon and the proteasome are susceptible to serine protease, as well as, cysteine protease inhibitors (30-33). As such, we hypothesize that approaches useful in developing inhibitors of proteasome activity may also be useful in developing inhibitors of bacterial Lon activity.

Although both nucleotide- and peptide- based inhibitors of Lon protease have been evaluated (30-32), none are highly potent or specific. Also, no detailed quantitative analysis has been done to allow comparison of these inhibitors. In this study, we aimed to quantitatively identify an inhibitor which could serve as a lead compound in the development of a potent Lon-specific inhibitor. We evaluated the steady-state kinetic parameters associated with both ATP and peptide hydrolysis by human and $S$. Typhimurium Lon. Although the ATP hydrolysis activities of both homologs are kinetically indistinguishable, they display differences in their substrate specificity. This suggests that a peptide-based inhibitor could be designed which would target bacterial Lon, thereby by decreasing side-effects due to cross-reactivity with human Lon. Using $S$. Typhimurium Lon as a model, we evaluated the $I C_{50}$ values of a series of commercially available peptide-based proteasome inhibitors. We have identified the peptidyl boronate, MG262, as a potent ATP-dependent inhibitor of $S$. Typhimurium Lon activity $\left(I C_{50}=122 \pm\right.$ $9 \mathrm{nM})$.

\section{Materials and Methods}

\section{Materials}

All oligonucleotide primers were purchased from Integrated DNA Technologies, Inc. (Coralville, IA). All cloning reagents were purchased from Promega (Madison, WI), New England BioLabs, Inc. (Ipswich, MA), Invitrogen (Carlsbad, CA) and USB Corporation (Cleveland, OH). Fmoc-protected amino acids, Boc-2-Abz-OH, Fmoc-Lys(Aloc)-Wang resin, Fmoc-Leu-Wang resin, Z-Leu-OSu and HBTU were purchased from Advanced ChemTech and NovaBiochem. MG262, epoxomicin and $\mathrm{ZL}_{3} \mathrm{VS}$ were purchased from Biomol International, LP. MG132 was purchased from BostonBiochem. Tris buffer, cell culture media, IPTG, chromatography media, DTT, $\operatorname{Mg}(\mathrm{OAc})_{2}$, trypsin, kanamycin, ATP, AMPPNP, ethylboronic acid, isopropylboronic acid, DMSO, SDS and EDTA were purchased from Fisher, Sigma and Amresco (Solon, OH).

\section{Plasmid Construction}

The Salmonella enterica serovar Typhimurium (S. Typhimurium) Lon gene was amplified from genomic DNA (a gift from D. Kehres in M. Maguire's lab at Case Western Reserve University School of Medicine) using the oligonucleotides 5'-

TAATACCCATGGGGAATCCTGAGCGTTCTGAA-3' and 5'- 
AAACCCAAGCTTCTACTATTTGCGGTTACAACCT-3'. The resultant PCR product was cloned into the NcoI and HindIII sites of pET24d(+) (Novagen) to create the plasmid pHF020. The NdeI-BamHI fragment from proEx-1/hLon (34) was cloned into pET24c+ (Novagen) to create the plasmid pHF002. Both plasmids express the mature wild type enzymes without any exogenous tags and were verified by DNA sequencing. Our $S$. Typhmurium Lon gene harbors a naturally occuring conservative mutation, V378I, which does not occur within the functional domains.

\section{Purification of Recombinant Lon}

Recombinant $S$. Typhimurium Lon was overexpressed in BL21 (DE3) (Novagen), using the plasmid pHF020, and purified as previously published for E. coli Lon (35) with the exception that $30 \mu \mathrm{g} / \mathrm{mL}$ Kan (Sigma) was used instead of $100 \mu \mathrm{g} / \mathrm{mL}$ Amp (Fisher). Recombinant human Lon was overexpressed in Rosetta (DE3) (Novagen), using the plasmid pHF002, and purified as described previously (36) with the following modifications. Following fractionation on a P11 column, the human Lon containing fractions were pooled and precipitated using saturated ammonium sulfate. The precipitate was recovered by centrifugation and resuspended in Solution A (36), containing $2 \mathrm{mM}$ DTT instead of $2 \mathrm{mM} \beta$-mercaptoethanol, and fractionated on a Superose 6 (Pharmacia) gel filtration column equilibrated in the same buffer. The concentration of Lon monomer was determined by Bradford assay, using BSA as a standard, and the purified protein stored at $-80^{\circ} \mathrm{C}$.

\section{Peptide Synthesis}

Synthesis of $\mathbf{1}, \mathbf{2}, \mathrm{ZL}_{3} \mathrm{OH}$, and the corresponding non-fluorescent analogs of $\mathbf{1}$ and $\mathbf{2}$ (Figure 1) were performed as previously described (35).

\section{Continuous Steady-State Peptide Hydrolysis Assay}

Steady-state velocity data were collected on a Fluoromax 3 spectrophotometer (Horiba Group) as previously described for $E$. coli Lon (35) with the following modifications. All reactions contained $50 \mathrm{mM}$ Tris (pH 8.1), $10 \mathrm{mM} \mathrm{Mg}(\mathrm{OAc})_{2}, 2 \mathrm{mM}$ DTT, $150 \mathrm{mM} \mathrm{NaCl}$ (human Lon reactions only), 125-200 nM $S$. Typhimurium Lon monomer or $900 \mathrm{nM}$ human Lon monomer, and varying concentrations of the peptide substrate (from 0-3.5 mM). At peptide concentrations between $100 \mu \mathrm{M}$ and $1 \mathrm{mM}$, a mixture of $10 \%$ fluorescent peptide and $90 \%$ of the corresponding non-fluorscent analog were used to avoid the inner filter effect. Likewise, at peptide concentrations greater than $1 \mathrm{mM}$, a mixture of $1 \%$ fluorescent peptide and $99 \%$ of the corresponding non-fluorescent analog were used to avoid the inner filter effect. After equilibration at $37^{\circ} \mathrm{C}$ for $1 \mathrm{~min}$, the reaction was initiated by the addition of $1 \mathrm{mM} \mathrm{ATP}$. The steady-state velocities were determined from the linear phase of the reaction time courses using KaleidaGraph (Synergy, Inc.). The steady-state kinetic parameters associated with peptide cleavage were determined by fitting the $k_{\text {obs }}$ data with eq 1 using the nonlinear regression program Prism 4 (GraphPad Software, Inc.).

$$
k_{o b s}=\frac{k_{c a t}[S]}{K_{m}{ }^{n}+[S]^{n}}
$$

where $k_{\mathrm{obs}}$ is the observed rate constant, $k_{\mathrm{cat}}$ is the maximal $k_{\mathrm{obs}}, \mathrm{S}$ is peptide substrate, $\mathrm{n}$ is the Hill coefficient, and $K_{\mathrm{m}}$ is the Michaelis-Menton constant. All experiments were performed at least in triplicate.

\section{Radiolabeled ATP Hydrolysis Assay}

Steady-state velocity data was collected as described previously (37). Briefly, reactions containing $50 \mathrm{mM}$ Tris (pH 8.1), $10 \mathrm{mM} \mathrm{Mg}(\mathrm{OAc})_{2}, 2 \mathrm{mM}$ DTT, $150 \mathrm{mM} \mathrm{NaCl}$ (human Lon reactions only), and $200 \mathrm{nM}$ Lon monomer in the presence and absence of $1.3 \mathrm{mM} 1$ or $2(\sim 5 \mathrm{x}$ 
$\left.K_{\mathrm{m}}\right)$ for $S$. Typhimurium Lon or $5 \mathrm{mM} 1\left(\sim 5 \mathrm{x} K_{\mathrm{m}}\right)$ for human Lon, were initiated by the addition of varying concentrations of $\left[\alpha_{-}{ }^{32} \mathrm{P}\right]$ ATP $(0-1 \mathrm{mM})$ and incubated at $37^{\circ} \mathrm{C}$. At different time points (from $0-20 \mathrm{~min}$ ), aliquots were quenched in $0.5 \mathrm{~N}$ formic acid. A $3 \mu \mathrm{L}$ aliquot of each quenched reaction time point was spotted onto a PEI-cellulose TLC plate $(10 \mathrm{~cm} \times 20 \mathrm{~cm})$ and the plate developed in $0.3 \mathrm{M} \mathrm{KP} i \mathrm{pH} 3.4)$. The amount of [ $\left.\alpha-{ }^{32} \mathrm{P}\right]$ ATP (ICN or Perkin-Elmer) and $\left[\alpha-{ }^{32} \mathrm{P}\right]$ ADP was quantified using a Packard Cyclone storage phosphor screen Phosphor imager (Perkin-Elmer Life Science) and the [ADP] generated calculated using eq 2.

$$
[A D P]=\left(\frac{A D P_{d l u}}{A T P_{d l u}+A D P_{d l u}}\right)[A T P]
$$

The steady-state velocities were then determined from the linear phase of a plot of the amount of ADP generated versus time using KaleidaGraph (Synergy, Inc.). The steady-state kinetic parameters associated with ATP hydrolysis were determined by fitting the $k_{\text {obs }}$ data with eq 3 using the nonlinear regression program Prism 4 (GraphPad Software, Inc.).

$$
k_{o b s}=\frac{k_{c a t}[S]}{K_{m}+[S]}
$$

where $k_{\mathrm{obs}}, k_{\mathrm{cat}}, \mathrm{S}$, and $K_{\mathrm{m}}$ are as defined in eq 1 . All experiments were performed at least in triplicate.

\section{Mass Spectrometry of Peptide Cleavage Products}

Reactions containing $50 \mathrm{mM}$ Tris (pH 8.1), $10 \mathrm{mM} \mathrm{Mg}(\mathrm{OAc})_{2}, 2 \mathrm{mM}$ DTT, $200 \mathrm{nM} S$. Typhimurium Lon monomer, and $100 \mu \mathrm{M}$ peptide substrate were initiated by the addition of $1 \mathrm{mM}$ ATP and incubated at $37^{\circ} \mathrm{C}$. After 0 and 10 minutes, aliquots of the reactions mixture were quenched in $0.15 \%$ TFA final and submitted for MALDI mass spectrometry analysis (University of Cincinnati Mass Spectrometry Facility).

\section{Determination of $\mathrm{IC}_{50}$ Values for Inhibitors}

Experiments were performed as described under Continuous Steady-State Peptidase Activity Assay with the following modifications. All reactions contained $50 \mathrm{mM}$ Tris $(\mathrm{pH} 8.1), 10 \mathrm{mM}$ $\mathrm{Mg}(\mathrm{OAc})_{2}, 2 \mathrm{mM}$ DTT, $300 \mathrm{nM} S$. Typhimurium Lon monomer, and 300 $\mu \mathrm{M} 2(10 \%$ fluorescent $/ 90 \%$ non-fluorescent, $K_{\mathrm{m}}$ level). Fifty seconds after initiation with $1 \mathrm{mM}$ ATP, varying concentrations of the inhibitor (in $2 \mu \mathrm{L} \mathrm{DMSO}$ ) was added. The time at which inhibitor was added was considered time zero. The steady-state velocities were determined from the linear phase of the reaction time courses using KaleidaGraph (Synergy, Inc.). The $I C_{50}$ under these conditions was determined by fitting the $k_{\mathrm{obs}}$ data with eq 4 (38).

$$
\frac{k_{o b s, i}}{k_{o b s}}=\frac{1}{1+\frac{[I]}{I C_{50}}}
$$

where $k_{\mathrm{obs}, \mathrm{i}}$ is the observed rate constant in the presence of inhibitor, $k_{\mathrm{obs}}$ is the observed rate constant in the absence of inhibitor, I is inhibitor, and $I C_{50}$ is the [I] under which $k_{\mathrm{obs}, \mathrm{i}} / k_{\mathrm{obs}}=$ 0.5. All experiments were performed in triplicate.

\section{Determination of ATP Dependence of MG262 Inhibition}

Steady-state velocity data were collected on a Fluoromax 3 spectrophotometer (Horiba Group) as previously described for $E$. coli Lon (35) with the following modifications. Reactions containing $50 \mathrm{mM}$ Tris ( $\mathrm{pH} 8.1), 10 \mathrm{mM} \mathrm{Mg}(\mathrm{OAc})_{2}, 2 \mathrm{mM}$ DTT, and $300 \mathrm{nM} S$. Typhimurium Lon monomer were equilibrated for $1 \mathrm{~min}$ at $37^{\circ} \mathrm{C}$ prior to the addition of $1.2 \mu \mathrm{M} \mathrm{MG} 262$. At the times indicated $1 \mathrm{mM}$ ATP or AMPPNP and $300 \mu \mathrm{M} 2$ (10\% fluorescent/90\% nonfluorescent, $K_{\mathrm{m}}$ level) were added. The time at which $\mathbf{2}$ was added was considered time zero. 


\section{Estimation of $\mathrm{K}_{\mathrm{i}}$ from $\mathrm{IC}_{50}$ Values}

To approximate the $K_{\mathrm{i}}$ values for MG132, MG262, ethylbornic acid and $\mathrm{ZL}_{3} \mathrm{OH}$, it was assumed that they were all competitive inhibitors of 2 . The $I C_{50}$ values determined previously were used to estimate $K_{\mathrm{i}}$ using eq 5 :

$$
I C_{50}=K_{i}\left(1+\frac{S_{2}}{k_{m, 2}}\right)
$$

where $I C_{50}$ is as defined as in eq $4, K_{\mathrm{i}}$ is the inhibition constant, $\mathrm{S}_{2}$ is the concentration of $\mathbf{2}$, and $K_{\mathrm{m}, 2}$ is the Michaelis-Menton constant for $\mathbf{2}$. To estimate the expected $K_{\mathrm{i}}$ for MG262 if it were simply a competitive, bivalent inhibitor made up of a peptide moiety $\left(\mathrm{ZL}_{3} \mathrm{OH}\right)$ and a boronate moiety (ethylbornic acid), we used eq 6-8 (39):

$$
\begin{aligned}
& \Delta G_{\text {binding, } Z L_{3} \mathrm{OH}}=R T \ln \left(K_{i, Z L_{3} \mathrm{OH}}\right) \\
& \Delta G_{\text {binding,ethyl }}=R T \ln \left(K_{i, \text { ethyl }}\right) \\
& \Delta G_{\text {binding, }, M G 262}=\Delta G_{\text {binding, ZL } L_{3} O H}+\Delta G_{\text {binding, ethyl }}=R T \ln \left(K_{i, M G 262}\right)
\end{aligned}
$$

where $\Delta G_{\text {binding, } \mathrm{ZL}{ }_{3} \mathrm{OH}}$ is the free energy of binding for $\mathrm{ZL}_{3} \mathrm{OH}, K_{i, \mathrm{ZL}_{3} \mathrm{OH}}$ is the inhibition constant for $\mathrm{ZL}_{3} \mathrm{OH}, \Delta G_{\text {binding,ethyl }}$ is the free energy of binding for ethylboronic acid, $K_{i, e t h y l}$ is the inhibition constant for ethylbornic acid, $\Delta G_{b i n d i n g, M G} 262$ is the estimated free energy of binding for MG262, and $K_{i, M G 262}$ is the estimated inhibition constant for MG262.

\section{Results}

\section{Cloning and Purification of Recombinant Lon}

The $S$. Typhimurium Lon gene was amplified from genomic DNA, cloned into the NcoI and HindIII sites of pET24d(+) (Novagen) and overexpressed in BL21 (DE3). The human Lon gene was amplified from proEx-1/hLon (34), cloned into the NdeI and BamHI sites of pET24c + (Novagen) and overexpressed in Rosetta (DE3). Both were purified to near homogeneity (Figure 2) as described in Materials and Methods. As much as $11 \mathrm{mg}$ of $S$. Typhimurium Lon and $1.2 \mathrm{mg}$ of human Lon can be purified from each liter of culture. The purified proteins are in their mature wild-type form and contain no exogenous tags, such as His or GST.

\section{Steady-State Kinetic Analysis of Peptide Cleavage}

We have previously developed a peptide substrate, $\mathbf{1}$, for fluorescent detection of peptide cleavage by $E$. coli Lon (40). Upon cleavage, an increase in fluorescence is observed as the $\mathrm{N}$ terminal 3-nitrotyrosine quencher separates from the C-terminal anthranilamide lysine fluorophore. We hypothesized that $\mathbf{1}$ could also be used to monitor proteolysis with recombinant $S$. Typhimurium and human Lon. In the absence of ATP, no peptide cleavage is observed, but in the presence of $1 \mathrm{mM}$ ATP, $S$. Typhimurium and human Lon degrade 1 (Figure $3 \mathrm{~A})$. As with E. coli Lon, a lag is observed in peptide cleavage prior to reaching the steadystate activity (35).

We determined the steady-state kinetic constants associated with ATP-dependent degradation of $\mathbf{1}$ by $S$. Typhimurium and human Lon. The observed rate constants $\left(k_{\mathrm{obs}}\right)$ for steady-state cleavage of varying concentrations of $\mathbf{1}$ in the presence of saturating ATP were measured and plotted as a function of $\mathbf{1}$ (Figure 3B). Both give a sigmoidal plot, but the kinetic parameters for the two homologs are different (Table 1). $S$. Typhimurium Lon degrades 1 in a manner comparable to E. coli Lon $(26,35)$. Human Lon, on the other hand, has a similar degree of cooperativity (n), but $k_{\text {cat }}$ is 2.5 -fold lower and $K_{\mathrm{m}}$ is 5 -fold greater than $S$. Typhimurium Lon 
(Table 1). This results in a $k_{\text {cat }} / K_{\mathrm{m}}$ for human Lon which is 10 -fold lower than $S$. Typhimurium Lon (Table 1).

Our model peptide, 1, contains a Cys residue (Figure 1), making its synthesis problematic, due to the resulting low yield. The presence of a Cys residue in our substrate is also unfavorable as it will react with any thiol-reactive inhibitors. To avoid these problems, we changed the Cys to the non-natural amino acid Abu, which replaces the thiol by a methyl group and is therefore isosteric with Cys. The resultant peptide (2) was cleaved by $S$. Typhimurium Lon with steadystate kinetic parameters comparable to those for $\mathbf{1}$ (Table 1). Mass spectral analysis of the $S$. Typhimurium Lon cleavage products of $\mathbf{1}$ and $\mathbf{2}$ verified that both peptides were cleaved at the same position (data not shown), as indicated in Figure 1.

To avoid the inner filter effect when determining the kinetic constants of peptide cleavage by the continuous peptide hydrolysis assay, mixtures of both fluorescent and non-fluorescent analogs of $\mathbf{1}$ and $\mathbf{2}$ were used. To rule out the possibility that the fluorescent and non-fluorescent analogs are degraded differently, the steady-state kinetic constants for peptide hydrolysis were also determined by a discontinuous peptide hydrolysis assay using only the fluorescent analog. Similar kinetic constants were obtained using either assay (see Supporting Information).

\section{Steady-State Kinetic Analysis of ATP Hydrolysis}

ATP hydrolysis by Lon protease occurs in the absence of a substrate (intrinsic ATP hydrolysis) and is increased or stimulated in the presence of a peptide $(40)$ or protein $(8,41)$ substrate (peptide- or protein-stimulated ATP hydrolysis, respectively). We determined the steady-state kinetic constants associated with ATP hydrolysis by recombinant $S$. Typhimurium and human Lon using a radiolabeled ATP hydrolysis assay (37). The $k_{\text {obs }}$ for steady-state ATP hydrolysis at varying concentrations of ATP both in the presence and absence of saturating $\mathbf{1}$ or $\mathbf{2}$ were measured and plotted as a function of ATP (Figure 4). Hyperbolic plots are obtained for both intrinsic and peptide-stimulated ATP hydrolysis by $S$. Typhimurium and human Lon. As expected, the intrinsic ATP hydrolysis activity of both homologs is stimulated by the presence of the peptide substrate. Similar kinetic constants for intrinsic and peptide-stimulated ATP hydrolysis are obtained irrespective of the homolog or peptide used (Table 2) and are comparable to those obtained previously with E. coli Lon (26).

\section{Determination of $\mathrm{IC}_{50}$ Values for Common Proteasome Inhibitors}

No potent or specific inhibitors of Lon protease activity are known. Due to mechanistic and structural similarities between Lon and HslUV $(26,28,42)$, the bacterial homolog of the proteasome, we screened a panel of commercially available peptide-based proteasome inhibitors to identify a lead compound, suitable for inhibiting Lon activity. Using $S$. Typhimurium Lon as a model, we determined the $I C_{50}$ values for several proteasome inhibitors (Table 3) with respect to $S$. Typhimurium Lon proteolysis activity at $300 \mu \mathrm{M} 2\left(K_{\mathrm{m}}\right.$ level) and saturating ATP. Due to the lag phase, we did not add the inhibitor until after the steady-state was reached. MG132, a peptidyl aldehyde, inhibited $S$. Typhimurium Lon activity with an $I C_{50}$ of $4.1 \pm 0.3 \mu \mathrm{M}$. Epoxomicin, a peptidyl epoxyketone, and $\mathrm{ZL}_{3} \mathrm{VS}$, a peptidyl vinyl sulfone, were ineffective at inhibiting $S$. Typhimurium Lon at micromolar concentrations (Table 3). All the proteasome inhibitors were dissolved in DMSO which did not affect $S$. Typhimurium Lon activity when it was less than $4 \%$ of the reaction volume (data not shown). Due to this limitation, the effect of higher concentrations of epoxomicin and $\mathrm{ZL}_{3} \mathrm{VS}$ could not be evaluated.

Most of the proteasome inhibitors were classical inhibitors of $S$. Typhimurium Lon activity, with inhibition occurring instantaneously upon addition. However, inhibition by MG262, a peptidyl boronate, was time dependent or biphasic (Figure 5A). When calculating the $I C_{50}$ for 
MG262 (Table 3), we used the rate of the second phase, as this was the final effect of inhibition. This resulted in an $I C_{50}$ of $122 \pm 9 \mathrm{nM}$ for MG262 (Figure 5B), making it the most potent of all inhibitors tested.

\section{Probing the Importance of the Peptide and Boronic Acid Moieties of MG262 in Inhibition}

MG262 has both a peptide and boronic acid moiety, both of which are important for inhibiting the proteasome (43). To explore the contribution of each of these moieties towards inhibition of $S$. Typhimuruium Lon activity, we determined the $I C_{50}$ for related compounds which resemble each moiety alone (Table 3). Ethylboronic acid and isopropylboronic acid were chosen as models for the boronic acid moiety of MG262. The $I C_{50}$ of ethylboronic acid could not be determined accurately due to solubility limitations, but was greater than $10 \mathrm{mM}$. Isopropylboroic acid, on the other hand, had an $I C_{50}$ of $810 \pm 50 \mu \mathrm{M}$ (Figure $5 \mathrm{C}$ ). We synthesized $\mathrm{ZL}_{3} \mathrm{OH}$ (Figure 4) as a model of the peptide moiety of MG262. The $I C_{50}$ of $\mathrm{ZL}_{3} \mathrm{OH}$ was $740 \pm 29 \mu \mathrm{M}$ (Figure 5D).

\section{ATP-Dependent Inhibition of S. Typhimurium Lon by MG262}

Previous work with E. coli Lon has shown that peptidyl chloromethyl ketones require ATP to inhibit Lon activity $(8,32)$. We wanted to know whether inhibition by MG262 also required ATP. To accomplish this, $S$. Typhimurium Lon was preincubated with MG262 for 0, 120, or $480 \mathrm{~s}$. After the preincubation period, $1 \mathrm{mM}$ ATP and $300 \mu \mathrm{M} 2$ were added and peptide cleavage monitored over $600 \mathrm{~s}$ (Figure 6A). No differences in the time courses were observed, indicating that inhibition by MG262 did not begin until the addition of ATP and 2. S.

Typhimurium Lon was then preincubated with MG262 and ATP for 0, 120, or $480 \mathrm{~s}$. After the preincubation period, 2 was added and peptide cleavage again monitored over $600 \mathrm{~s}$ (Figure $6 \mathrm{~B})$. As the length of the preincubation period was increased, time dependency was lost. In fact, preincubation for $480 \mathrm{~s}$ resulted in a total loss of time dependency. Control reactions were performed in which MG262 was omitted (DMSO only). The presence of ATP alone during the preincubation period did not affect the rate of peptide hydrolysis, thus the loss of time dependency was the direct result of inhibition by MG262 and not ATP depletion or ADP inhibition (data not shown). Regardless of the length of the preincubation period, the final steady-state rates were identical $(29 \pm 6 \mathrm{nM} / \mathrm{s})$.

It has previously been shown that E. coli Lon requires binding, but not hydrolysis, of ATP in order to cleave a peptide substrate, albeit at a reduced rate (35). To determine whether inhibition by MG262 required both binding and hydrolysis of ATP, we repeated the latter experiment (preincubation with MG262 and nucleotide) with $1 \mathrm{mM}$ AMPPNP (Figure 6C). The same trend was observed with AMPPNP as with ATP. Time dependency was lost as the preincubation period was increased and the steady-state rates were identical regardless of the preincubation time ( $34 \pm 5 \mathrm{nM} / \mathrm{s})$. Control reactions were again performed without MG262 (DMSO only) and peptide hydrolysis was not affected by the presence of AMPPNP during the preincubation period (data not shown), thus the observed trend was the direct result of inhibition by MG262.

\section{Discussion}

Lon protease is an ATP-dependent serine protease and has emerged as a target in the development of novel antibiotics. To date, no potent or specific inhibitors of this enzyme have been described. In this study, we use steady-state kinetic techniques to quantitatively evaluate a series of commercially available inhibitors in order to identify a lead compound for future development of a bacterial Lon-specific inhibitor.

Lon catalyzes the hydrolysis of both ATP and proteins within different domains, presenting two possible approaches in developing Lon inhibitors. We evaluated the steady-state kinetic 
parameters for peptide and ATP hydrolysis to investigate which approach would allow an inhibitor to discriminate between $S$. Typhimurium and human Lon. The parameters associated with ATP-hydrolysis are similar for both (Table 2$)$, however the catalytic efficiency $\left(k_{\text {cat }} t\right.$ $K_{\mathrm{m}}$ ) of peptide degradation by human Lon is 10 -fold lower than $S$. Typhimurium Lon (Table 1). This implies there is a difference in the substrate specificity of the two homologs. This is not unexpected, as the two localize differently and would degrade a vastly different protein pool $(8,16)$. We conclude that a peptide-based approach to developing an inhibitor would be more useful as the observed difference in substrate specificity could potentially be exploited to target an inhibitor specifically to bacterial Lon, thereby decreasing the chance for side-effects resulting from cross-reactivity with the human homolog.

Lon is unique in that while classified as a serine protease, it is susceptible to both serine and cysteine protease inhibitors (30-32). Of the soluble ATP-dependent proteases within the $\mathrm{AAA}^{+}$superfamily, Lon more closely resembles proteases within the proteasome family (26, $27,29,42)$. As such, we began our search for a Lon inhibitor by screening a series of commercially available peptide-based proteasome inhibitors. In choosing inhibitors for our screen, we attempted to choose those containing similar peptide sequences, with only the reactive functional group varying. In this way, we could still evaluate the ability of each functional group to inhibit Lon without the need to synthesize a new series of inhibitors. Using a standard set of conditions, $300 \mu \mathrm{M} 2$ ( $K_{\mathrm{m}}$ level), $300 \mathrm{nM} S$. Typhimurium Lon, and saturating ATP, we determined the $I C_{50}$ for each inhibitor in our series (Table 3 ).

Peptidyl vinyl sulfones were designed to inhibit cysteine proteases via Michael addition (44), however they were later shown to react with both serine and theronine proteases (45-48). We tested the peptidyl vinyl sulfone $\mathrm{ZL}_{3} \mathrm{VS}$ as an inhibitor of $S$. Typhimurium Lon activity, but it did not appear to have any inhibitory effect (Table 3). The reason for the lack of inhibition is unclear. We believe this indicates the orientation of the active site residues, with respect to the peptide binding pocket, are different between the proteasome and Lon, thereby misaligning the vinyl sulfone for nucleophilic attack.

The natural product epoxomicin, a peptidyl epoxyketone, is the most selective proteasome inhibitor known due to its unique mechanism of inhibition (49,50). The final covalent adduct is a morpholino ring which contains not only the Thr hydroxyl, but also the $\mathrm{N}$-terminal amino group (51). The crystal structure of the protease domain of $E$. coli Lon was determined with a proteolytically inactive mutant, thus the orientation of the nucleophilic hydroxyl group is unknown, as well as how this hydroxyl affects the orientation of the $\varepsilon$-amino group of the proposed Ser-Lys dyad (42). We hypothesized that if the Ser-Lys dyad of Lon was indeed analogous to the catalytic dyad of the proteasome, epoxomicin inhibition of Lon would provide further insight into the orientation of these residues. Unfortunately, epoxomicin was unable to inhibit $S$. Typhimurium Lon (Table 3). Thus, we are able only to conclude that the orientation of the active site residues of both Lon and the proteasome are different. This result reinforces the unique specificity of epoxomicin for the proteasome.

Peptidyl aldhydes and boronates were designed to function as transition state analog inhibitors of proteolytic enzymes, with an active site thiol or hydroxyl, via formation of a tetrahedral adduct (43,52-55). Peptidyl aldehydes inhibit cysteine, serine, and theronine proteases effectively, with some preference for cysteine due to the higher nucleophilicity of the thiol. Peptidyl boronates, on the other hand, are much more potent against serine and theronine proteases due to the weakness of the boron-sulfur bond in the covalent adduct with cysteine (43). MG132, a peptidyl aldehyde, and MG262, a peptidyl boronate, both inhibit $S$. Typhimurium Lon, with $I C_{50}$ values of $4.1 \pm 0.3 \mu \mathrm{M}$ and $122 \pm 9 \mathrm{nM}$, respectively (Table 3 ,Figure $5 \mathrm{~B})$. The $K_{\mathrm{i}}$ value for each can estimated from the $I C_{50}$ value ( $2 \mu \mathrm{M}$ for MG132, 60 $\mathrm{nM}$ for MG262) as described under Materials and Methods (39). Although these are some of 
the best inhibitors of Lon known to date, both are $~ 2000$-fold more potent against the 20S proteasome (43). This weaker reactivity of MG132 and MG262 towards $S$. Typhimurium Lon may imply the local environment of the active site renders the hydroxyl less nucleophilic than in the proteasome and/or the peptide sequence is not optimal for binding to Lon. It is clear that transition state analogs will be useful in developing of more potent inhibitors of Lon activity.

Our best inhibitor, MG262, has both a peptide and boronic acid moiety, both of which are important for inhibition of the 20S proteasome (43). To determine the importance of each of these moieties in $S$. Typhimurium Lon inhibition, we determined the $I C_{50}$ for compounds representing each moiety seperately. To model the boronate moiety alone, we chose both ethyland isopropylboronic acid. The $I C_{50}$ of ethylboronic acid was $>10 \mathrm{mM}$, however the $I C_{50}$ for isopropylboronic was $810 \pm 50 \mu \mathrm{M}$ (Table 3,Figure 5C). The observed difference in $I C_{50}$ for the two compounds is unknown, however we speculate that the larger alkyl group may help anchor the boronic acid in the active site, thereby facilitating inhibition. We also synthesized the peptide $\mathrm{ZL}_{3} \mathrm{OH}$ as a mimic of the peptide moiety of MG262 and found it had an $I C_{50}$ of $740 \pm 29 \mu \mathrm{M}$ (Table 3,Figure 5D). Neither the boronate nor peptide alone could achieve the nanomolar potency found for MG262. We can again approximate the $K_{\mathrm{i}}$ using the $I C_{50}$ values, as described under Material and Methods, and obtain $5 \mathrm{mM}$ for ethylboronic acid and $400 \mu \mathrm{M}$ for $\mathrm{ZL}_{3} \mathrm{OH}$ (39). If we consider MG262 a bivalent inhibitor made up of the boronate and peptide moieties, we would, at best, expect an $I C_{50}$ of $\sim 4 \mu \mathrm{M}$ (39). In reality, MG262 is actually 30 -fold more potent (Table 3 ), indicating the inhibition is more complicated than simply increased affinity and will require further investigation.

Inhibition of $E$. coli Lon by peptidyl chloromethyl ketones requires ATP $(8,32)$, therefore we suspected that MG262 may also require ATP for inhibition. Preincubation of MG262 with $S$. Typhimurium Lon for varying lengths of time in the absence of ATP did not affect the degradation of 2 (Figure 6A). In presence of ATP, as the preincubation time was increased, time-dependency was lost (Figure 6B), however the steady-state rates remained the same (29 $\pm 6 \mathrm{nM} / \mathrm{s})$. Looking at the time course with no preincubation period ( $0 \mathrm{~s}$, Figure $6 \mathrm{~B})$, we see that after $480 \mathrm{~s}, S$. Typhimurium Lon has achieved steady-state turnover. If the presence of ATP during the preincubation period allowed for the formation of the MG262-inhibited species, we would predict that preincubation for 480 s would be enough time for maximal inhibition to occur. Thus upon the addition of $\mathbf{2}$, no time dependency would be expected and the linear plot should have a steady-state rate which matches that for no preincubation. This is exactly what we observe ( $480 \mathrm{~s}$, Figure 6B). Time dependency only appears to be lost because less active $S$. Typhimurium Lon is available upon the addition of $\mathbf{2}$. The time dependent inactivation occurs during the preincubation period. The ATP-dependence of MG262 inhibition of $S$. Typhimurium Lon is of mechanistic importance. It implies MG262 is a mechanism-based inhibitor of Lon and that inhibitors cannot simply diffuse into the active site, the ATP is required to deliver the inhibitor to the active site. Inhibition of HsIUV by peptidebased inhibitors also requires ATP, further supporting our use of HsIUV as a model for Lon (45).

To investigate whether MG262 inhibition required both binding and hydrolysis of ATP, we preincubated $S$. Typhimurium Lon with MG262 and the non-hydrolyzable ATP analog AMPPNP for varying lengths of time. If only ATP binding was required, we would again expect to see an apparent loss of time dependency as the preincubation time is increased, but the steady-state rate remain constant. From Figure $6 \mathrm{C}$, we see that this trend is indeed obtained (steady-state rate $=34 \pm 5 \mathrm{nM} / \mathrm{s}$ ). Thus MG262 inhibition requires only ATP binding and not hydrolysis.

Based upon the data obtained during this study, we propose the following mechanism (Scheme 1) to account for MG262 inhibition of $S$. Typhimurium Lon. First, the substrates must bind to 
$S$. Typhimurium Lon, creating a ternary complex (Scheme 1, step 1). It has previously been shown that ATP binding induces a conformational change in both E. coli Lon and HslUV and that in HsIUV, this conformational change results in the productive alignment of the substrate with the active site Thr of HslUV $(26,46,56)$. Based on these observations, we believe $S$. Typhimurium Lon next undergoes a conformation change (Lon*) within the ternary complex as a result of ATP binding (Scheme 1, step 2). This conformational change correctly aligns the boronate moiety of MG262 for nucleophilic attack by the active site Ser. It is only at this point that covalent modification of $S$. Typhimurium Lon by MG262 (Lon*-MG262) occurs to give the final inhibited binary species (Scheme 1, step 3). Although the covalent modification is reversible, the equilibrium would lie towards the covalently modified species (unpublished data) which is consistent with MG262 inhibition of the 20S proteasome (33). The first two steps appear to be fast, as inhibition by $\mathrm{ZL}_{3} \mathrm{OH}$ occurs immediately upon addition (i.e., it is a classical inhibitor) (data not shown). We believe the last step is slow due to the observation of time-dependent inhibition by MG262 (Figure 5A). Further studies are currently being undertaken to determine these details and confirm the proposed mechanism.

In this study we have shown that bacterial and human Lon display differences in substrate specificity which may be exploited in the future to discriminate between the homologs. We have demonstrated the use of a peptidyl boronic acid, MG262, as a potent ATP-dependent inhibitor of $S$. Typhimurium Lon activity. It should be noted that proteasome inhibitors, such as MG132, are able to diffuse into the mitochondria and inhibit the degradation of the steroidogenic acute regulatory protein (StAR), a physiological substrate of mammalian Lon $(57,58)$. It also been shown that the proteasome inhibitor bortezomib, a peptidyl boronate currently used in the treatment of multiply myeloma, causes mitochondrial damage by an unknown mechanism $(59,60)$. Thus, it is imperative that detailed kinetic analysis of the inhibition profile of human Lon by these peptide-based inhibitors be performed, as well as determine of the mechanism by which these inhibitors affect Lon activity, so that crossreactivity with other proteases, and other homologs of Lon, are minimized.

\section{Supplementary Material}

Refer to Web version on PubMed Central for supplementary material.

\section{Acknowledgements}

We would like to thank Diana Vineyard, Jessica Ward, and Xuemei Zhang for their assistance in preparing this manuscript.

\section{The abbreviations used are}

ATP, adenosine triphosphate

AMPPNP, adenosine 5'-( $\beta, \gamma$-imino)triphosphate

ADP, adenosine diphosphate

$\mathrm{KP}_{\mathrm{i}}$, potassium phosphate

DTT, dithiothreitol

Abz, anthranilamide

Bz, benzoic acid amide

Abu, 2-aminobuytric acid

3- $\mathrm{NO}_{2}, 3$-nitro

Aloc, allyloxycarbonyl

$\mathrm{OSu}, N$-hydroxysuccinimide ester

HBTU, O-Benzotriazole- $N, N, N^{\prime}, N^{\prime}$-tetramethyl-uronium-hexafluoro-phosphate

GST, glutathione S-transferase

Tris, 2-amino-2-(hydroxymethyl)-1,3-propanediol 
$\mathrm{Mg}(\mathrm{OAc})_{2}$, magnesium acetate

Fmoc, 9-fluorenylmethoxycarbonyl

Boc, butoxycarbonyl

$\mathrm{Z}$, benzyloxycarbonyl

PEI, polyethyleneimine

$\mathrm{Z}, N^{\alpha}$-benzyloxycarbonyl

$\mathrm{ZL}_{3} \mathrm{VS}, N^{\alpha}$-benzyloxycarbonyl-L-leucyl-L-leucyl-L-leucinyl vinyl sulfone

$\mathrm{ZL}_{3} \mathrm{OH}, N^{\alpha}$-benzyloxycarbonyl-L-leucyl-L-leucyl-L-leucine

SDS, sodium dodecyl sulfate

DMSO, dimethylsulfoxide

EDTA, ethylenediaminetetraacetic acid

Amp, ampicillin

Kan, kanamycin

dlu, density light unit.

\section{References}

1. Monaghan RL, Barrett JF. Antibacterial drug discovery--then, now and the genomics future. Biochem Pharmacol 2006;71:901-909. [PubMed: 16494849]

2. Robertson GT, Kovach ME, Allen CA, Ficht TA, Roop RM 2nd. The Brucella abortus Lon functions as a generalized stress response protease and is required for wild-type virulence in BALB/c mice. Mol Microbiol 2000;35:577-588. [PubMed: 10672180]

3. Takaya A, Suzuki M, Matsui H, Tomoyasu T, Sashinami H, Nakane A, Yamamoto T. Lon, a stressinduced ATP-dependent protease, is critically important for systemic Salmonella enterica serovar typhimurium infection of mice. Infect Immun 2003;71:690-696. [PubMed: 12540547]

4. Matsui H, Suzuki M, Isshiki Y, Kodama C, Eguchi M, Kikuchi Y, Motokawa K, Takaya A, Tomoyasu T, Yamamoto T. Oral immunization with ATP-dependent protease-deficient mutants protects mice against subsequent oral challenge with virulent Salmonella enterica serovar typhimurium. Infect Immun 2003;71:30-39. [PubMed: 12496146]

5. Charette MF, Henderson GW, Doane LL, Markovitz A. DNA-stimulated ATPase activity on the lon (CapR) protein. J Bacteriol 1984;158:195-201. [PubMed: 6325386]

6. Chung CH, Goldberg AL. The product of the lon (capR) gene in Escherichia coli is the ATP-dependent protease, protease La. Proc Natl Acad Sci U S A 1981;78:4931-4935. [PubMed: 6458037]

7. Goff SA, Goldberg AL. Production of abnormal proteins in E. coli stimulates transcription of lon and other heat shock genes. Cell 1985;41:587-595. [PubMed: 3886165]

8. Goldberg AL, Moerschell RP, Chung CH, Maurizi MR. ATP-dependent protease La (lon) from Escherichia coli. Methods Enzymol 1994;244:350-375. [PubMed: 7845219]

9. Goldberg AL, Waxman L. The role of ATP hydrolysis in the breakdown of proteins and peptides by protease La from Escherichia coli. J Biol Chem 1985;260:12029-12034. [PubMed: 2931432]

10. Gottesman S. Proteases and their targets in Escherichia coli. Annu Rev Genet 1996;30:465-506. [PubMed: 8982462]

11. Gottesman S, Gottesman M, Shaw JE, Pearson ML. Protein degradation in E. coli: the Ion mutation and bacteriophage lambda $\mathrm{N}$ and cll protein stability. Cell 1981;24:225-233. [PubMed: 6453650]

12. Gottesman S, Maurizi MR. Regulation by proteolysis: energy-dependent proteases and their targets. Microbiol Rev 1992;56:592-621. [PubMed: 1480111]

13. Maurizi MR. Proteases and protein degradation in Escherichia coli. Experientia 1992;48:178-201. [PubMed: 1740190]

14. Schoemaker JM, Gayda RC, Markovitz A. Regulation of cell division in Escherichia coli: SOS induction and cellular location of the sulA protein, a key to lon-associated filamentation and death. J Bacteriol 1984;158:551-561. [PubMed: 6327610]

15. Suzuki CK, Kutejova E, Suda K. Analysis and purification of ATP-dependent mitochondrial lon protease of Saccharomyces cerevisiae. Methods Enzymol 1995;260:486-494. [PubMed: 8592469] 
16. Wang N, Maurizi MR, Emmert-Buck L, Gottesman MM. Synthesis, processing, and localization of human Lon protease. J Biol Chem 1994;269:29308-29313. [PubMed: 7961901]

17. Huang X, Miller W. A Time-Efficient, Linear-Space Local Similarity Algorithm. Advances in Applied Mathematics 1991;12:337-357.

18. Apte BN, Rhodes H, Zipser D. Mutation blocking the specific degradation of reinitiation polypeptides in E. coli. Nature 1975;257:329-331. [PubMed: 1099462]

19. Downs D, Waxman L, Goldberg AL, Roth J. Isolation and characterization of lon mutants in Salmonella typhimurium. J Bacteriol 1986;165:193-197. [PubMed: 3001022]

20. Gottesman S, Zipser D. Deg phenotype of Escherichia coli lon mutants. J Bacteriol 1978;133:844851. [PubMed: 146704]

21. Grossman AD, Burgess RR, Walter W, Gross CA. Mutations in the Ion gene of E. coli K12 phenotypically suppress a mutation in the sigma subunit of RNA polymerase. Cell 1983;32:151-159. [PubMed: 6337720]

22. Howard-Flanders P, Simson E, Theriot L. A Locus That Controls Filament Formation And Sensitivity To Radiation In Escherichia Coli K-12. Genetics 1964;49:237-246. [PubMed: 14124942]

23. Mizusawa S, Gottesman S. Protein degradation in Escherichia coli: the lon gene controls the stability of sulA protein. Proc Natl Acad Sci U S A 1983;80:358-362. [PubMed: 6300834]

24. Dougan DA, Mogk A, Zeth K, Turgay K, Bukau B. AAA+ proteins and substrate recognition, it all depends on their partner in crime. FEBS Lett 2002;529:6-10. [PubMed: 12354604]

25. Patel S, Latterich M. The AAA team: related ATPases with diverse functions. Trends Cell Biol 1998;8:65-71. [PubMed: 9695811]

26. Patterson J, Vineyard D, Thomas-Wohlever J, Behshad R, Burke M, Lee I. Correlation of an adeninespecific conformational change with the ATP-dependent peptidase activity of Escherichia coli Lon. Biochemistry 2004;43:7432-7442. [PubMed: 15182186]

27. Wang J, Song JJ, Seong IS, Franklin MC, Kamtekar S, Eom SH, Chung CH. Nucleotide-dependent conformational changes in a protease-associated ATPase HsIU. Structure (Camb) 2001;9:11071116. [PubMed: 11709174]

28. Botos I, Melnikov EE, Cherry S, Khalatova AG, Rasulova FS, Tropea JE, Maurizi MR, Rotanova TV, Gustchina A, Wlodawer A. Crystal structure of the AAA+ alpha domain of E. coli Lon protease at 1.9A resolution. J Struct Biol 2004;146:113-122. [PubMed: 15037242]

29. Lowe J, Stock D, Jap B, Zwickl P, Baumeister W, Huber R. Crystal structure of the 20S proteasome from the archaeon T. acidophilum at 3.4 A resolution. Science 1995;268:533-539. [PubMed: 7725097]

30. Bota DA, Davies KJ. Lon protease preferentially degrades oxidized mitochondrial aconitase by an ATP-stimulated mechanism. Nat Cell Biol 2002;4:674-680. [PubMed: 12198491]

31. Waxman L, Goldberg AL. Protease La from Escherichia coli hydrolyzes ATP and proteins in a linked fashion. Proc Natl Acad Sci U S A 1982;79:4883-4887. [PubMed: 6214787]

32. Waxman L, Goldberg AL. Protease La, the lon gene product, cleaves specific fluorogenic peptides in an ATP-dependent reaction. J Biol Chem 1985;260:12022-12028. [PubMed: 3900067]

33. Kisselev AF, Goldberg AL. Proteasome inhibitors: from research tools to drug candidates. Chem Biol 2001;8:739-758. [PubMed: 11514224]

34. Fu GK, Markovitz DM. The human LON protease binds to mitochondrial promoters in a singlestranded, site-specific, strand-specific manner. Biochemistry 1998;37:1905-1909. [PubMed: 9485316]

35. Thomas-Wohlever J, Lee I. Kinetic characterization of the peptidase activity of Escherichia coli Lon reveals the mechanistic similarities in ATP-dependent hydrolysis of peptide and protein substrates. Biochemistry 2002;41:9418-9425. [PubMed: 12135363]

36. Liu T, Lu B, Lee I, Ondrovicova G, Kutejova E, Suzuki CK. DNA and RNA binding by the mitochondrial lon protease is regulated by nucleotide and protein substrate. J Biol Chem 2004;279:13902-13910. [PubMed: 14739292]

37. Gilbert SP, Mackey AT. Kinetics: a tool to study molecular motors. Methods 2000;22:337-354. [PubMed: 11133240] 
38. Copeland, RA. Enzymes: A Practical Introduction to Structure, Mechanism, and Data Analysis. 2nd ed.. John Wiley \& Sons, Inc.; New York: 2000.

39. Copeland, RA. Evaluation of Enzyme Inhibitors in Drug Discovery: A Guide for Medicinal Chemists and Pharmacologists. John Wiley \& Sons, Inc.; Hoboken, NJ: 2005.

40. Lee I, Berdis AJ. Adenosine triphosphate-dependent degradation of a fluorescent lambda N substrate mimic by Lon protease. Anal Biochem 2001;291:74-83. [PubMed: 11262158]

41. Waxman L, Goldberg AL. Selectivity of intracellular proteolysis: protein substrates activate the ATPdependent protease (La). Science 1986;232:500-503. [PubMed: 2938257]

42. Botos I, Melnikov EE, Cherry S, Tropea JE, Khalatova AG, Rasulova F, Dauter Z, Maurizi MR, Rotanova TV, Wlodawer A, Gustchina A. The catalytic domain of Escherichia coli Lon protease has a unique fold and a Ser-Lys dyad in the active site. J Biol Chem 2004;279:8140-8148. [PubMed: 14665623]

43. Adams J, Behnke M, Chen S, Cruickshank AA, Dick LR, Grenier L, Klunder JM, Ma YT, Plamondon L, Stein RL. Potent and selective inhibitors of the proteasome: dipeptidyl boronic acids. Bioorg Med Chem Lett 1998;8:333-338. [PubMed: 9871680]

44. Palmer JT, Rasnick D, Klaus JL, Bromme D. Vinyl sulfones as mechanism-based cysteine protease inhibitors. J Med Chem 1995;38:3193-3196. [PubMed: 7650671]

45. Bogyo M, McMaster JS, Gaczynska M, Tortorella D, Goldberg AL, Ploegh H. Covalent modification of the active site threonine of proteasomal beta subunits and the Escherichia coli homolog HslV by a new class of inhibitors. Proc Natl Acad Sci U S A 1997;94:6629-6634. [PubMed: 9192616]

46. Sousa MC, Kessler BM, Overkleeft HS, McKay DB. Crystal structure of HslUV complexed with a vinyl sulfone inhibitor: corroboration of a proposed mechanism of allosteric activation of HslV by HslU. J Mol Biol 2002;318:779-785. [PubMed: 12054822]

47. Joyeau R, Maoulida C, Guillet C, Frappier F, Teixeira AR, Schrevel J, Santana J, Grellier P. Synthesis and activity of pyrrolidinyl- and thiazolidinyldipeptide derivatives as inhibitors of the Tc80 prolyl oligopeptidase from Trypanosoma cruzi. Eur J Med Chem 2000;35:257-266. [PubMed: 10758287]

48. Bogyo M, Shin S, McMaster JS, Ploegh HL. Substrate binding and sequence preference of the proteasome revealed by active-site-directed affinity probes. Chem Biol 1998;5:307-320. [PubMed: 9653549]

49. Meng L, Mohan R, Kwok BH, Elofsson M, Sin N, Crews CM. Epoxomicin, a potent and selective proteasome inhibitor, exhibits in vivo antiinflammatory activity. Proc Natl Acad Sci U S A 1999;96:10403-10408. [PubMed: 10468620]

50. Hanada M, Sugawara K, Kaneta K, Toda S, Nishiyama Y, Tomita K, Yamamoto H, Konishi M, Oki T. Epoxomicin, a new antitumor agent of microbial origin. J Antibiot (Tokyo) 1992;45:1746-1752. [PubMed: 1468981]

51. Groll M, Kim KB, Kairies N, Huber R, Crews CM. Crystal structure of epoxomicin: 20S proteasome reveals a molecular basis for selectivity of a',b'-epoxyketone proteasome inhibitors. J Am Chem Soc 2000;122:1237-1238.

52. Koehler KA, Lienhard GE. 2-phenylethaneboronic acid, a possible transition-state analog for chymotrypsin. Biochemistry 1971;10:2477-2483. [PubMed: 5557796]

53. Thompson RC. Use of peptide aldehydes to generate transition-state analogs of elastase. Biochemistry 1973;12:47-51. [PubMed: 4734224]

54. Westerik JO, Wolfenden R. Aldehydes as inhibitors of papain. J Biol Chem 1972;247:8195-8197. [PubMed: 4640942]

55. Vinitsky A, Michaud C, Powers JC, Orlowski M. Inhibition of the chymotrypsin-like activity of the pituitary multicatalytic proteinase complex. Biochemistry 1992;31:9421-9428. [PubMed: 1356435]

56. Yoo SJ, Kim HH, Shin DH, Lee CS, Seong IS, Seol JH, Shimbara N, Tanaka K, Chung CH. Effects of the cys mutations on structure and function of the ATP-dependent HsIVU protease in Escherichia coli. The Cys 287 to Val mutation in HslU uncouples the ATP-dependent proteolysis by HslvU from ATP hydrolysis. J Biol Chem 1998;273:22929-22935. [PubMed: 9722513]

57. Granot Z, Geiss-Friedlander R, Melamed-Book N, Eimerl S, Timberg R, Weiss AM, Hales KH, Hales DB, Stocco DM, Orly J. Proteolysis of normal and mutated steroidogenic acute regulatory proteins in the mitochondria: the fate of unwanted proteins. Mol Endocrinol 2003;17:2461-2476. [PubMed: 12958217] 
58. Ondrovicova G, Liu T, Singh K, Tian B, Li H, Gakh O, Perecko D, Janata J, Granot Z, Orly J, Kutejova E, Suzuki CK. Cleavage site selection within a folded substrate by the ATP-dependent lon protease. J Biol Chem 2005;280:25103-25110. [PubMed: 15870080]

59. Ling YH, Liebes L, Zou Y, Perez-Soler R. Reactive oxygen species generation and mitochondrial dysfunction in the apoptotic response to Bortezomib, a novel proteasome inhibitor, in human H460 non-small cell lung cancer cells. J Biol Chem 2003;278:33714-33723. [PubMed: 12821677]

60. Pei XY, Dai Y, Grant S. The proteasome inhibitor bortezomib promotes mitochondrial injury and apoptosis induced by the small molecule Bcl-2 inhibitor HA14-1 in multiple myeloma cells. Leukemia 2003;17:2036-2045. [PubMed: 14513055] 


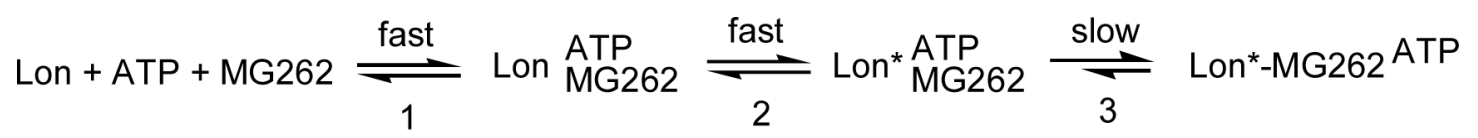

1 - substrate binding

2 - conformational change

3 - covalent modification

\section{Scheme 1.}




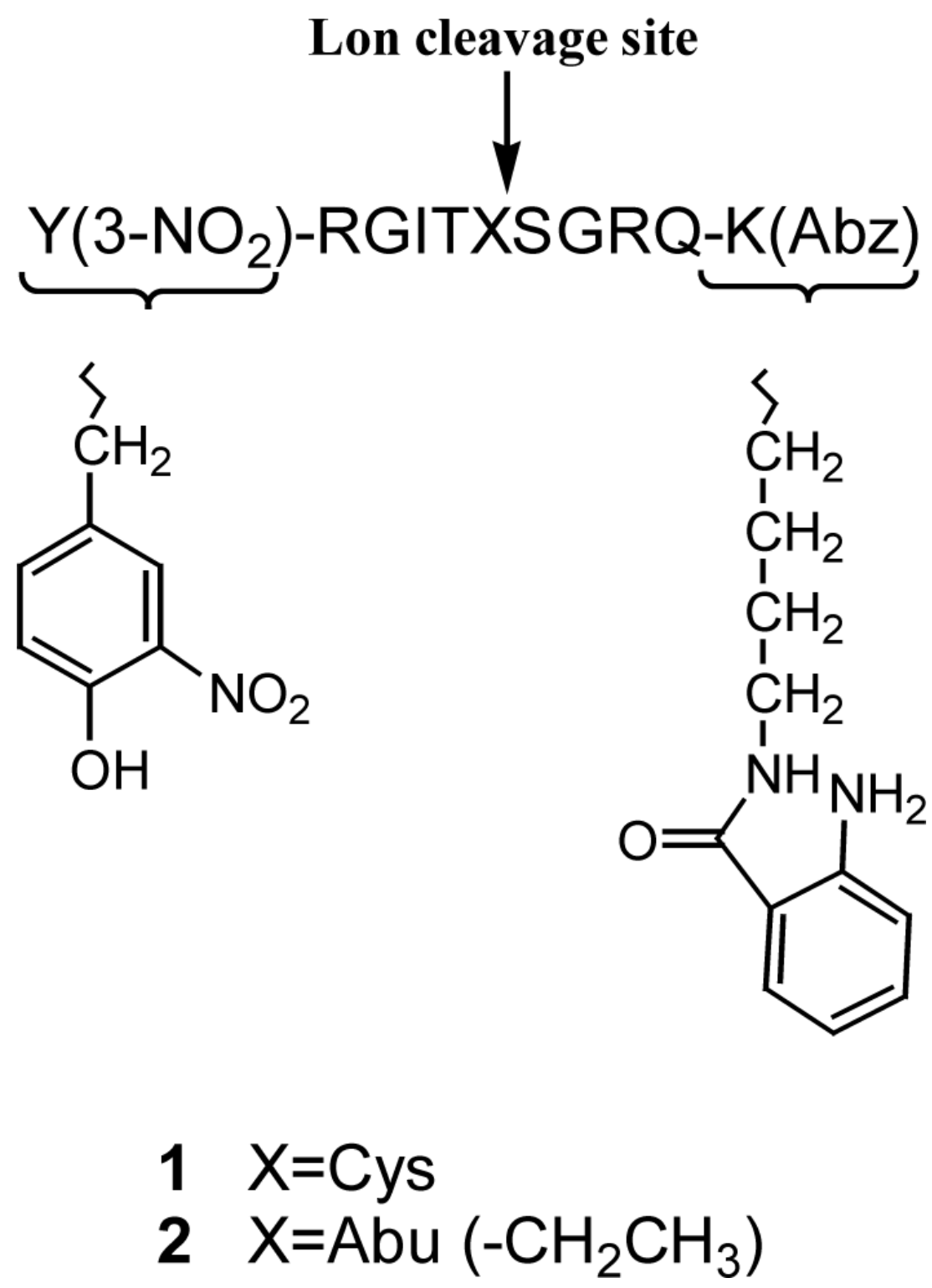

Figure 1. Substrates for continuous fluorescent measurement of Lon peptide cleavage Upon Lon cleavage between $\mathrm{X}$ and $\mathrm{S}$, an increase in fluorescence is observed as the fluorphore, $\mathrm{K}(\mathrm{Abz})$ (lysine anthranilamide), and quencher, $\mathrm{Y}\left(3-\mathrm{NO}_{2}\right)$ (3-nitrotyrosine) separate. The amino acids which flank the scissile bond, P1 (X) and P1', are labeled. In the non-fluorescent analogs, the $\mathrm{Y}\left(3-\mathrm{NO}_{2}\right)$ is replaced by $\mathrm{Y}$ and the $\mathrm{K}(\mathrm{Abz})$ is replaced by $\mathrm{K}(\mathrm{Bz})$ (lysine benzoic acid amide). 

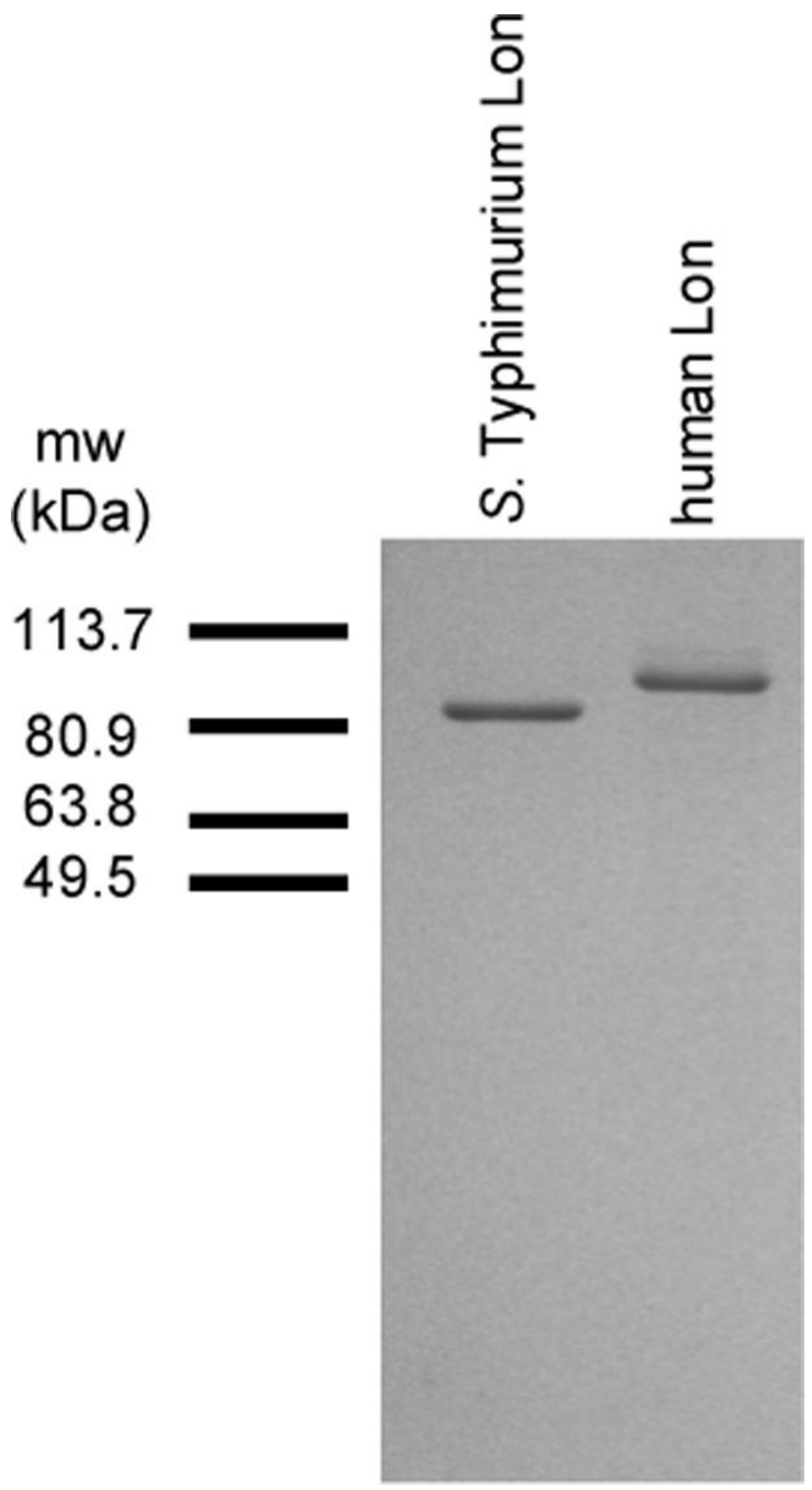

Figure 2. Coomassie stain of purified recombinant $S$. Typhimurium and human Lon SDS-PAGE of $\sim 365 \mathrm{ng}$ purified recombinant $S$. Typhimurium (87 kDa) and human Lon (95 $\mathrm{kDa}$ ) visualized by coomassie. 


\section{S. Typhimurium Lon}

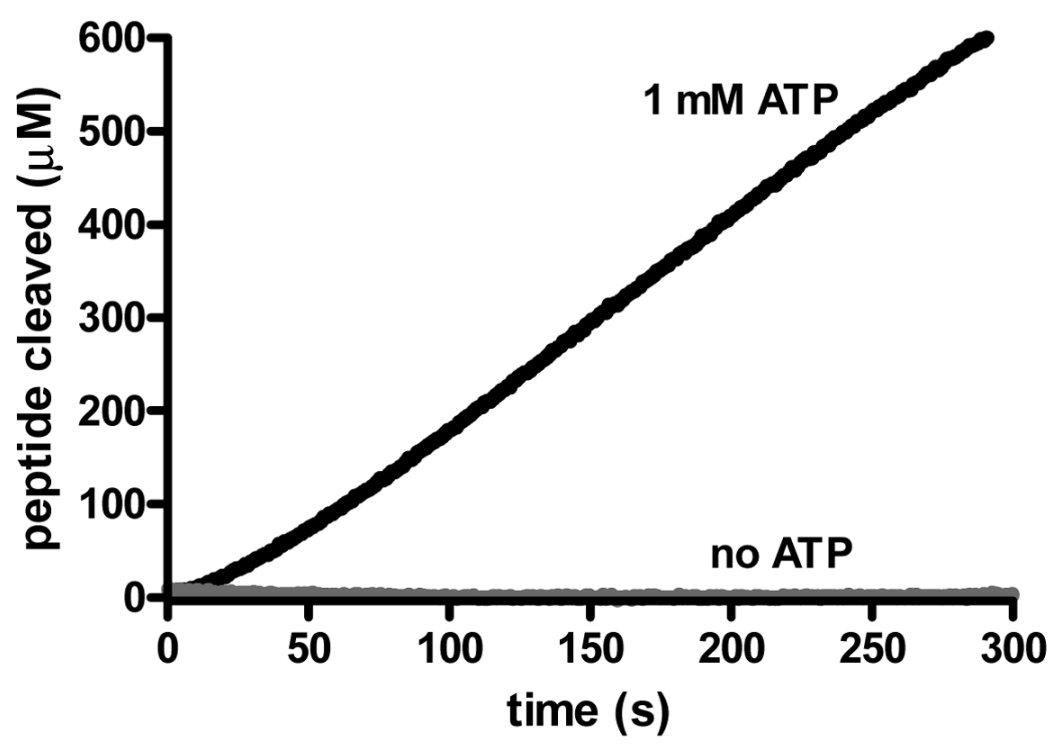

human Lon

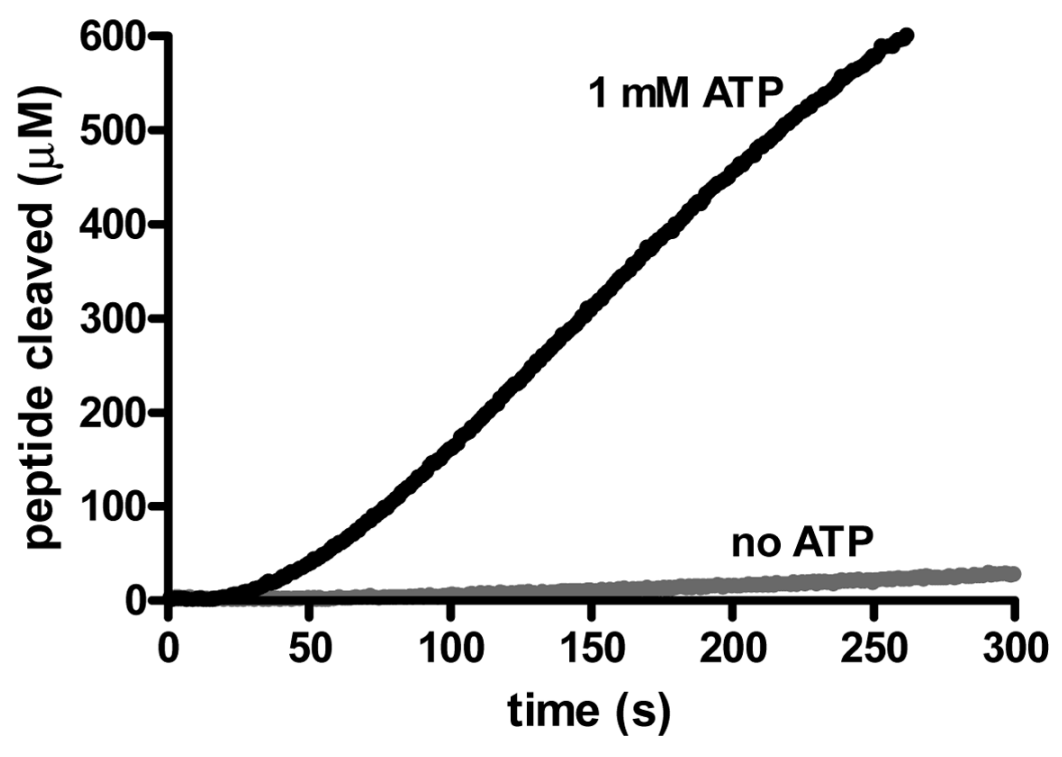




\section{S. Typhimurium Lon}

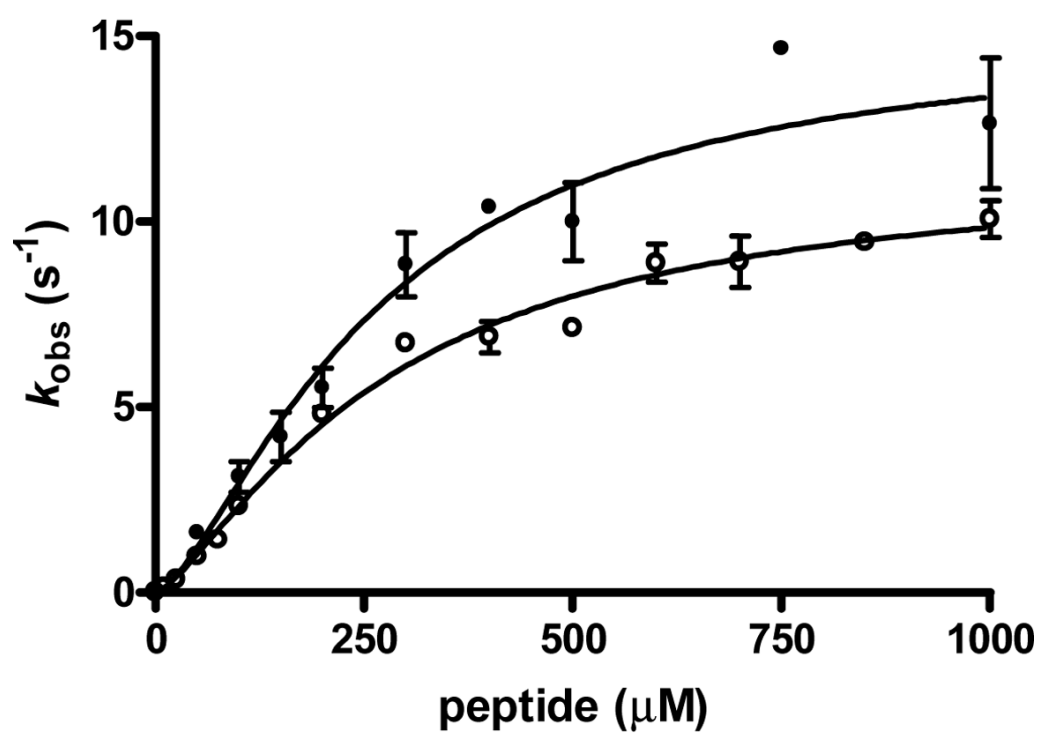

\section{human Lon}

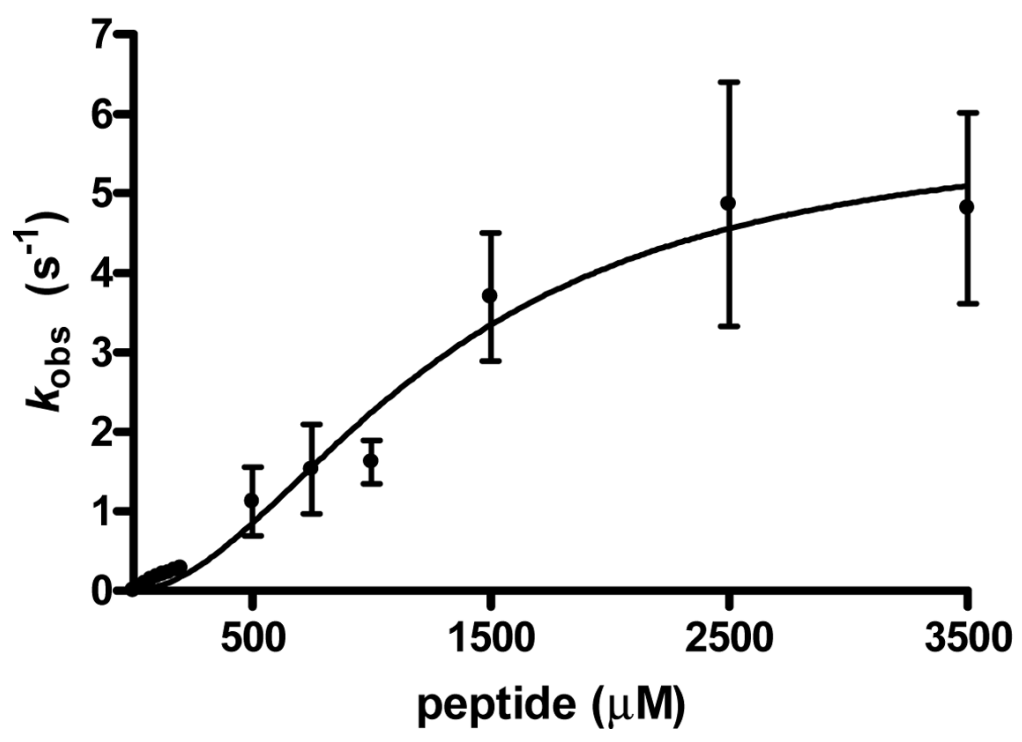

Figure 3. Steady-state peptide cleavage by S. Typhimurium and human Lon

(A) Representative time courses for $S$. Typhimurium $(125 \mathrm{nM})$ and human $(900 \mathrm{nM})$ Lon degradation of $1(1 \mathrm{mM})$ in the presence and absence of ATP. (B) Reactions containing $S$. Typhimurium or human Lon were preincubated with varying concentrations of $\mathbf{1}(\bullet)$ or $\mathbf{2}(\mathrm{O})$ prior to the addition of $1 \mathrm{mM}$ ATP. All experiments were preformed at least in triplicate and the averaged $k_{\text {obs }}$ values $( \pm 1 \mathrm{SD})$ were plotted against the corresponding peptide concentration. The data were best fit with the Hill equation (eq 1) as described in Materials and Methods. 

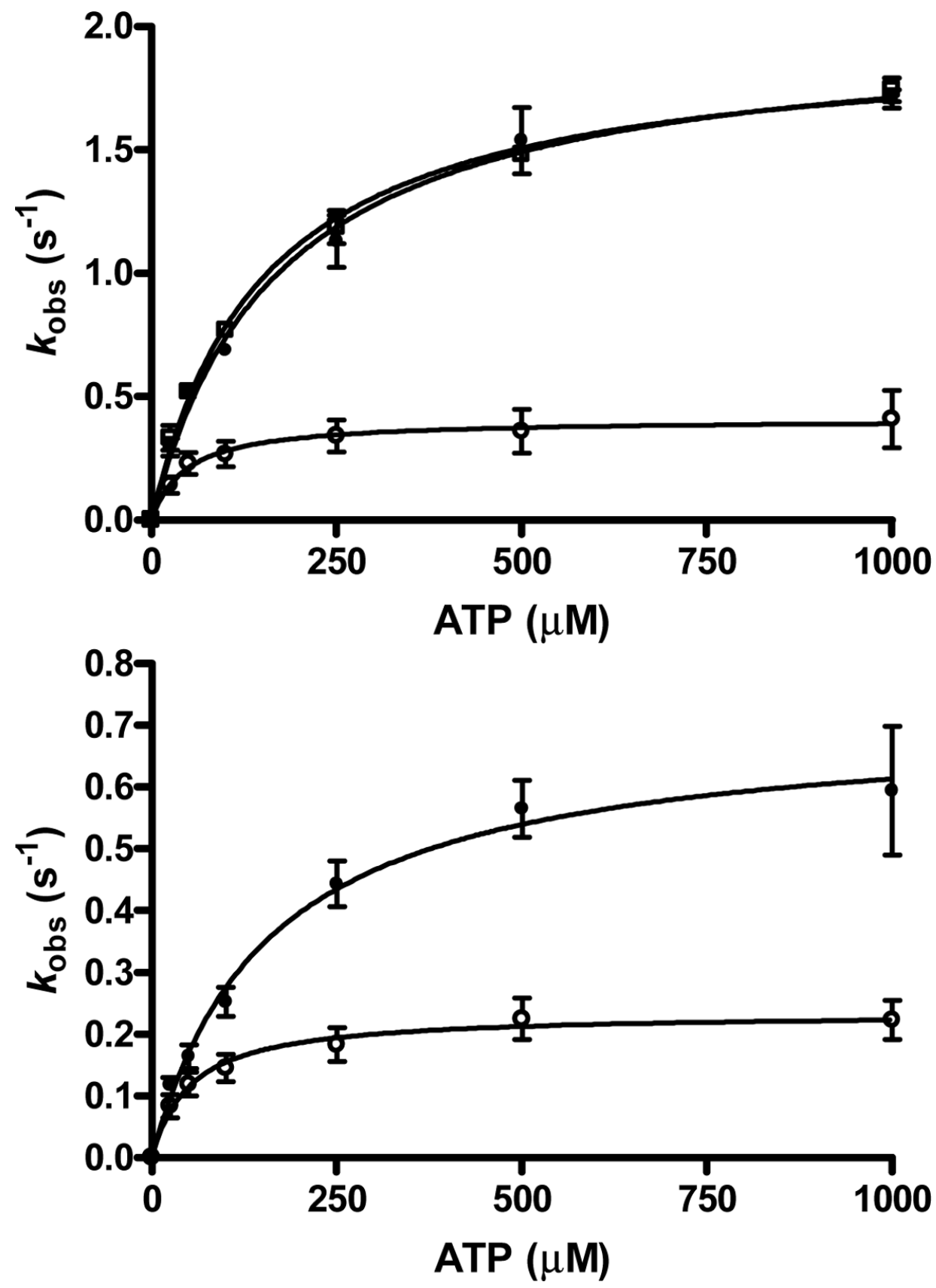

Figure 4. Steady-state ATP hydrolysis by S. Typhimurium and human Lon Reactions containing $S$. Typhimurium (A) or human Lon (B) were preincubated in the absence (०) and presence of saturating $\left(\sim 5 \mathrm{x} K_{\mathrm{m}}\right) \mathbf{1}(\bullet)$ or $\mathbf{2}(\square)$ prior to the addition of varying concentrations of ATP. All experiments were preformed at least in triplicate and the averaged $k_{\text {obs }}$ values $( \pm 1 \mathrm{SD}$ ) were plotted against the corresponding ATP concentration. The data were best fit with the Michaelis-Menton equation as described in Materials and Methods. 

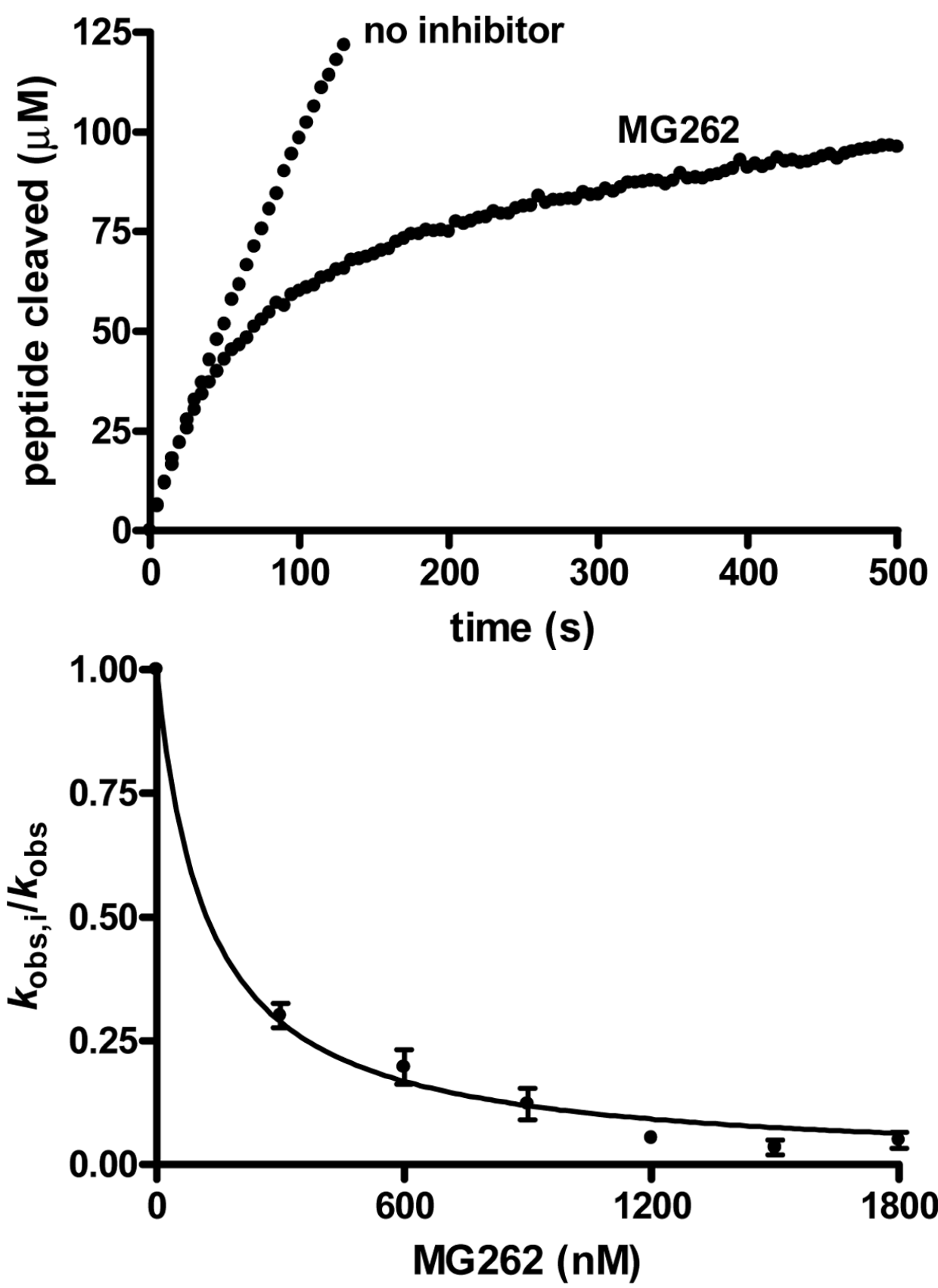

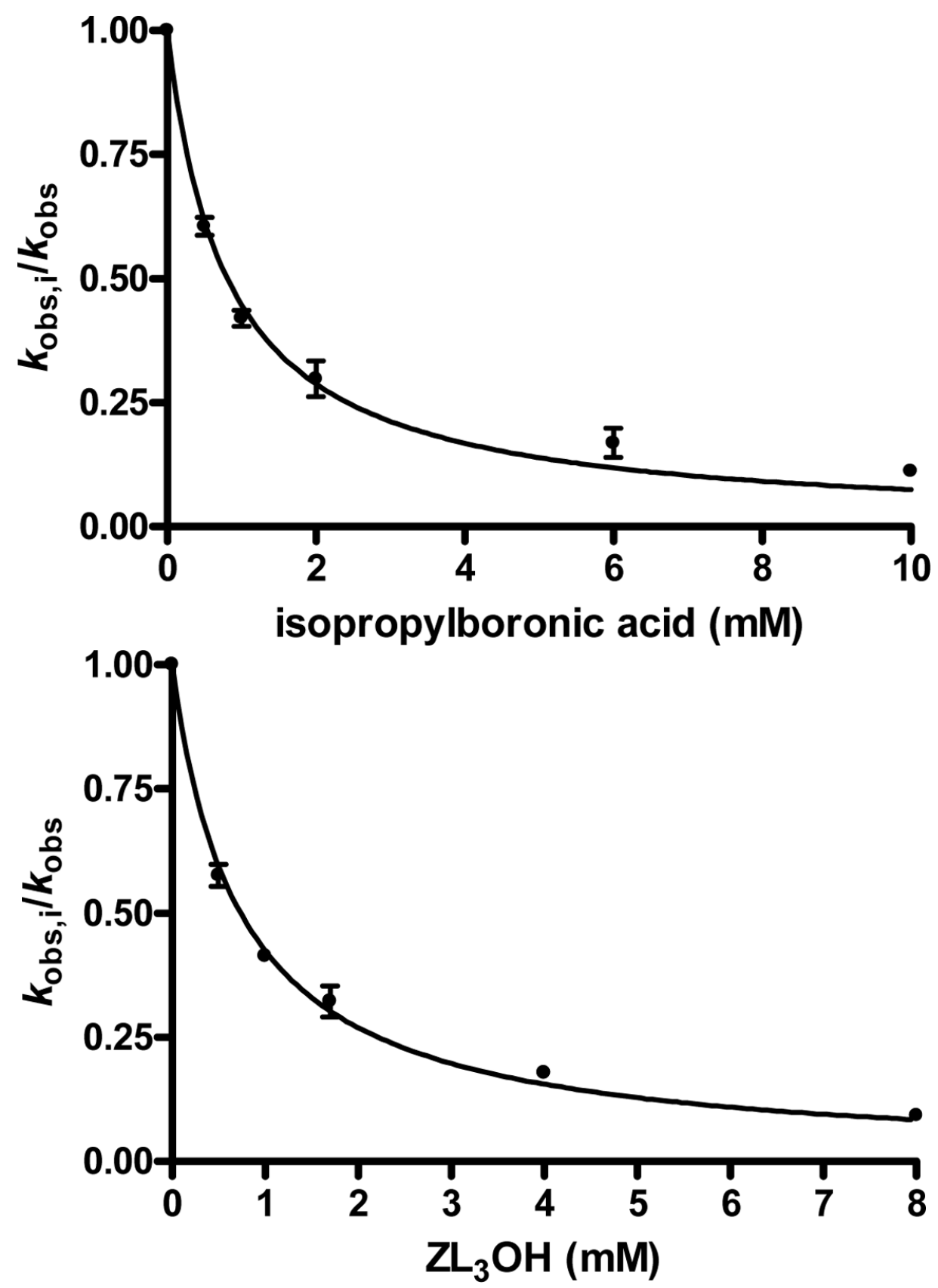

Figure 5. Inhibition of S. Typhimurium Lon degradation of 2

(A) Representative time courses for $S$. Typhimurium Lon (300 nM) degradation of 2 (300 $\mu \mathrm{M}, K_{\mathrm{m}}$ level) in the absence and presence of MG262 $(0.9 \mu \mathrm{M})$. (B-D) Reactions containing $300 \mathrm{nM} S$. Typhimurium Lon were preincubated with $300 \mu \mathrm{M} 2\left(K_{\mathrm{m}}\right.$ level) prior to the addition of $1 \mathrm{mM}$ ATP. After $50 \mathrm{~s}, 2 \mu \mathrm{L}$ inhibitor in DMSO was added and peptide cleavage monitored over $550 \mathrm{~s}$. All experiments were preformed in triplicate and the $k_{\mathrm{obs}}$ values determined as described in Materials and Methods. The averaged $k_{o b s}$ in the presence of inhibitor $/ k_{\text {obs }}$ in the absence of inhibitor $\left(k_{\mathrm{obs}, \mathrm{i}} / k_{\mathrm{obs}}, \pm 1 \mathrm{SD}\right)$ were plotted against the corresponding inhibitor concentration. The $I C_{50}$ for each inhibitor was determined by fitting the data as described in Materials and Methods. Inhibition by MG262 (B) resulted in an $I C_{50}=122 \pm 9 \mathrm{nM}$, inhibition 
by isopropylboronic acid (C) yielded an $I C_{50}=810 \pm 50 \mu \mathrm{M}$, and inhibition $\mathrm{ZL}_{3} \mathrm{OH}$ resulted in an $I C_{50}=740 \pm 29 \mu \mathrm{M}$. 

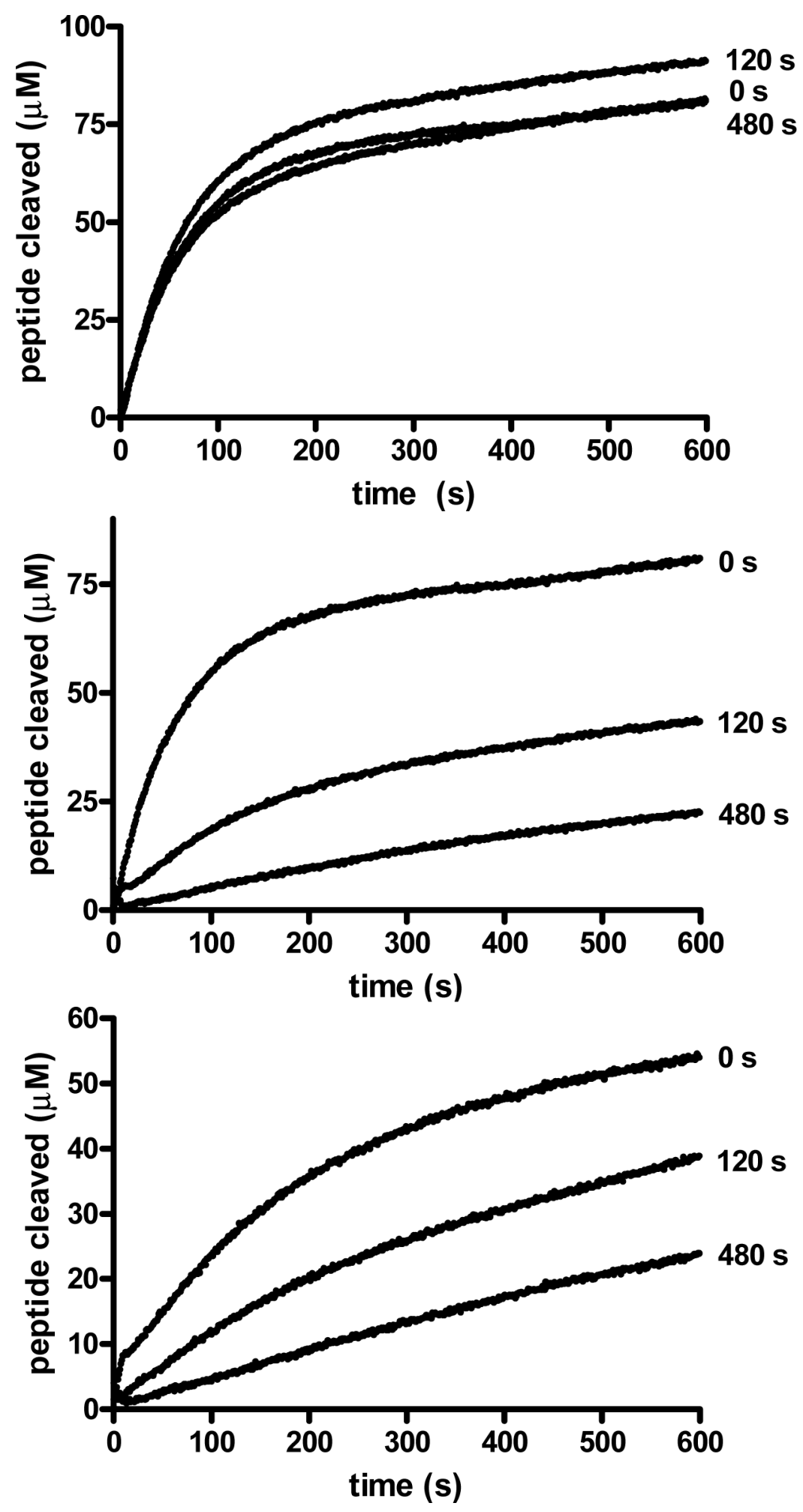

Figure 6. MG262 inhibition of S. Typhimurium Lon requires ATP

Reactions containing $300 \mathrm{nM}$. Typhimurium Lon were preincubated with $1.2 \mu \mathrm{M}$ MG262

(A), $1.2 \mu \mathrm{M}$ MG262 and $1 \mathrm{mM}$ ATP (B), or $1.2 \mu \mathrm{M}$ MG262 and $1 \mathrm{mM}$ AMPPNP prior to the addition of $300 \mu \mathrm{M} 2$ and $1 \mathrm{mM}$ ATP (A only) after the indicated time. Peptide cleavage was 
monitored over $600 \mathrm{~s}$. All experiments were preformed in triplicate and the averaged time courses plotted against time. 
Table 1

Summary of Steady-State Kinetic Parameters for Peptide Hydrolysis

\begin{tabular}{|c|c|c|c|}
\hline & \multicolumn{2}{|c|}{ S. Typhimurium Lon } & \multirow{2}{*}{$\begin{array}{c}\text { human Lor } \\
1\end{array}$} \\
\hline & 1 & 2 & \\
\hline$k_{\text {cat }}\left(\mathrm{s}^{-1}\right)$ & $15 \pm 2$ & $11 \pm 1$ & $5.9 \pm 0.7$ \\
\hline$K_{m}(\mu \mathbf{M})$ & $262 \pm 61$ & $276 \pm 38$ & $1300 \pm 200$ \\
\hline$k_{\mathrm{cat}} / K_{\mathrm{m}}\left(\times 10^{3} \mathrm{M}^{-1} \mathrm{~s}^{-1}\right)$ & 57 & 40 & 4.5 \\
\hline $\mathbf{n}$ & $1.5 \pm 0.3$ & $1.4 \pm 0.2$ & $1.9 \pm 0.3$ \\
\hline
\end{tabular}




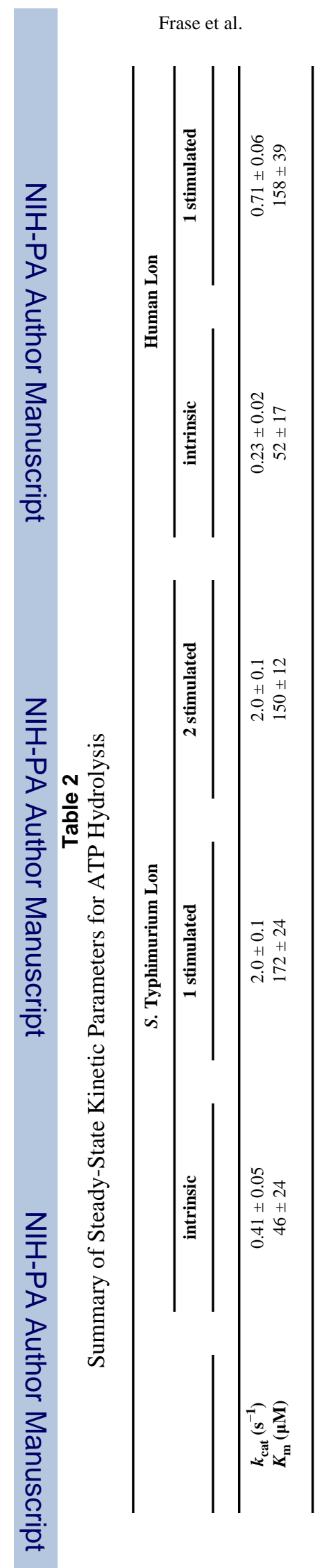

Biochemistry. Author manuscript; available in PMC 2008 August 13. 
Table 3

Summary of $I C_{50}$ Values for Inhibition of $S$. Typhimurium Lon

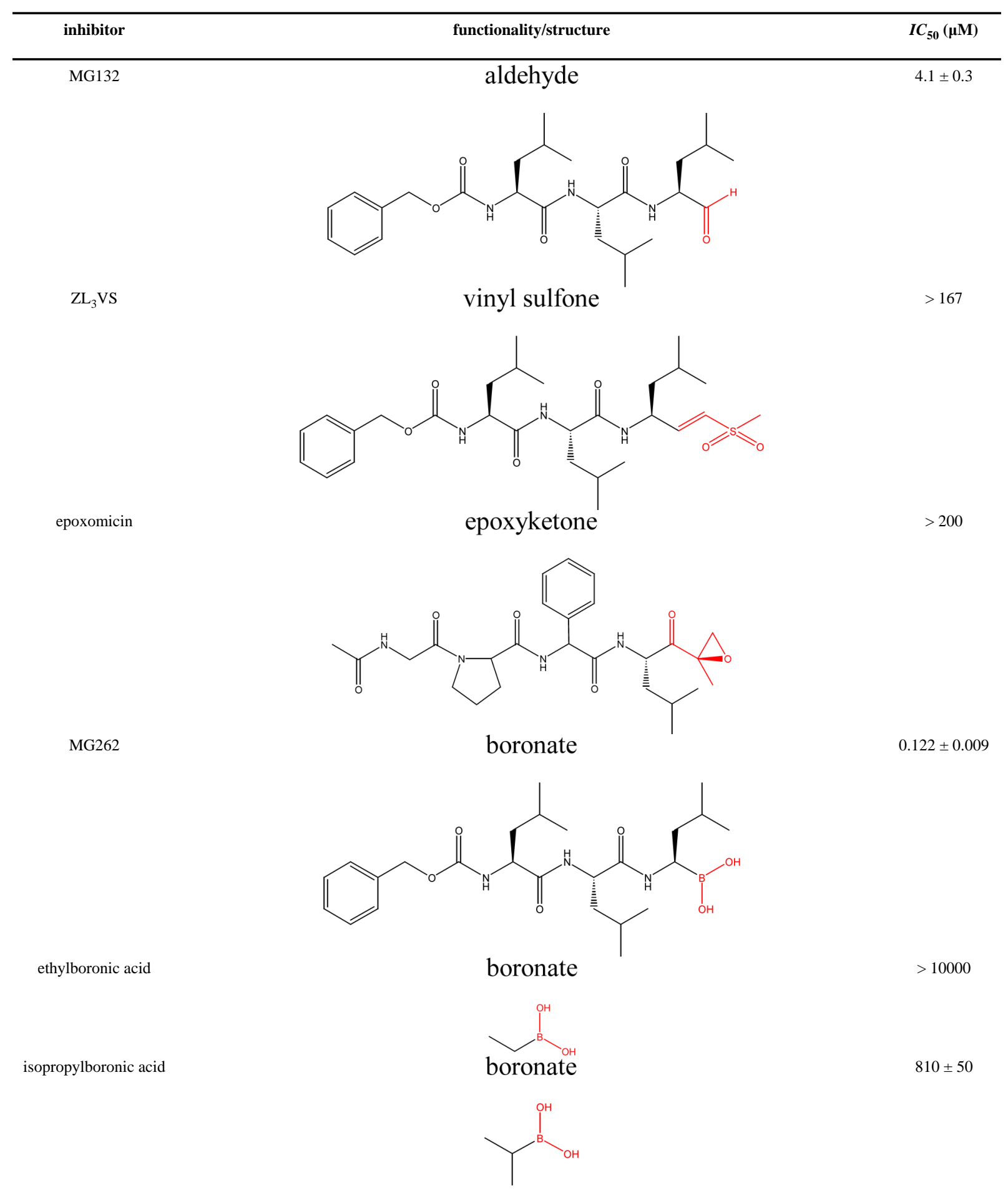




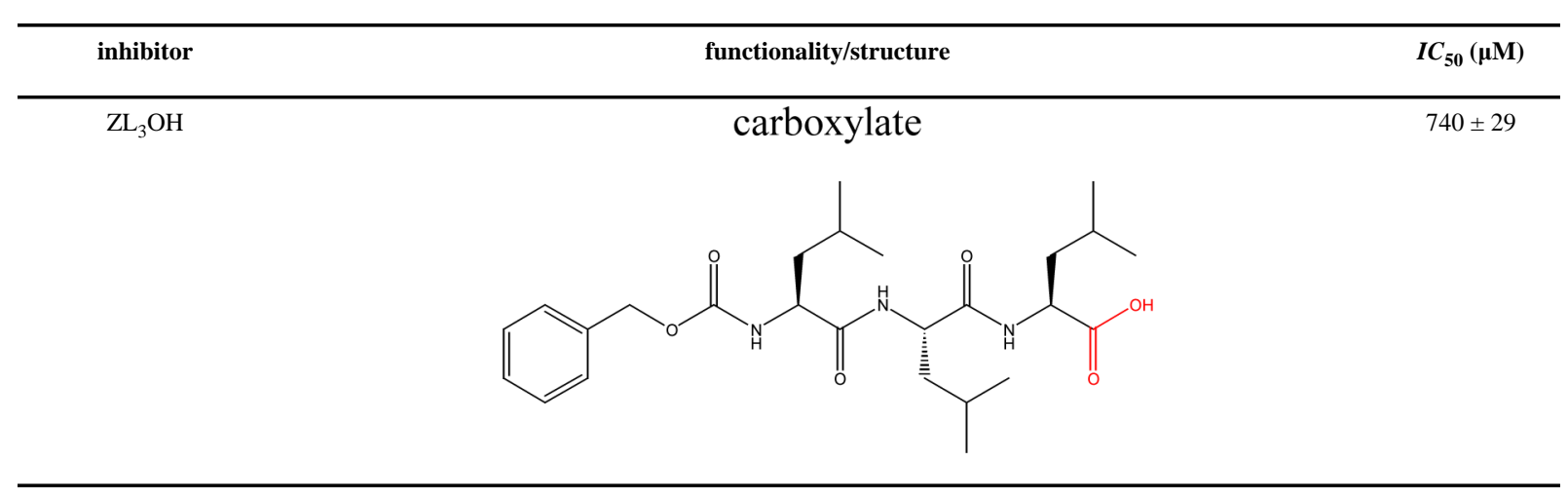

